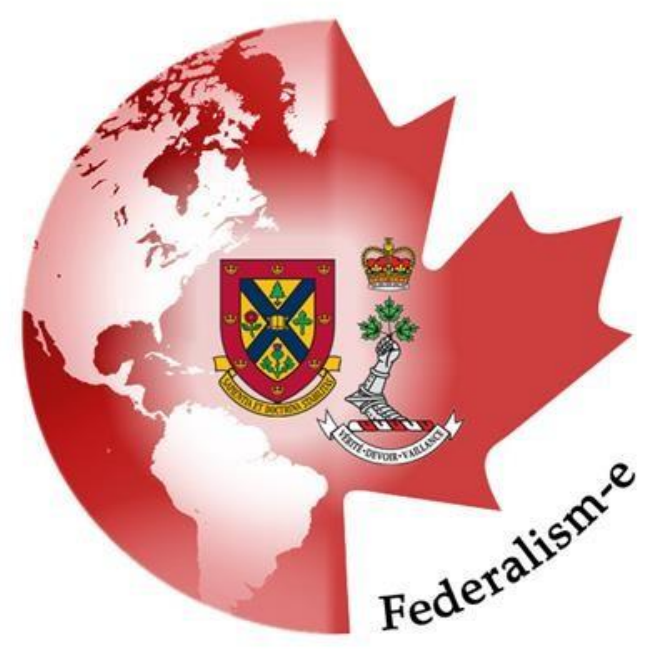

\title{
Power Sharing: The Separation of Power in a Political System
}

Melissa Sanfacon, Royal Military College of Canada

Corruption and the abuse of power within a political system would be inevitable without regulation. Political writers and philosophers have theorized about how to control the abuse of power for centuries. A solution, though evolving over time, was introduced through the concept of sharing power amongst multiple government entities and across different levels of government. This essay will discuss the sharing of power in regards to the following: theoretical origins of thought, methods of sharing power including the separation of power and federalism, and how these concepts operate. These elements will be discussed in order to assert the importance of sharing power within a political system. The Canadian system of government will be used as an example to display how the abuse of power is shared within a political system. Sharing power amongst multiple government entities, and across different levels of government, is an essential component of modern liberal-democratic politics because it confers legitimacy on a government by preventing the abuse of power.

Prior to analyzing methods of sharing power, the separation of power and federalism, it is first necessary to introduce the origins of this type of thought. John Locke 
and Baron Montesquieu, both modern political philosophers, introduced and developed the notion of separation of power. To begin, John Locke, an English liberal thinker in the 1700 s, put an emphasis on the importance of the separation of powers in a political system. He believed that there is legitimacy in government when power is separated.(Tuckness, 2005) In turn, Locke introduced the idea of separation of powers, which refers to a system in which the three branches of government "are kept separate in order to prevent the abuse of power". (Legal Information Institute: Separation of Powers) In his writing, Second Treatise of Government, Locke expresses the roles of each branch of government. It is expressed that "in a constituted commonwealth", there can be "but one supreme power, which is the legislative". (Locke, 1980, p.77) The Legislative is seen as the supreme power because any entity that "can give laws to another, must [need] to be superior to him". (Locke, 1980, p.78) Locke also explains the role of the executive branch of government, in relation to the legislative, but leaves the judiciary as an institution rather than a distinct branch of government. Locke places an emphasis on the separation of powers across multiple branches of government because this is one of the most effective ways of legitimizing government. (Locke, 1980, p.78) Separating powers across different entities ensures that power will not be abused, and allows the other branches to verify power is being exerted properly.

The concept of separation of power was coined by John Locke, as mentioned above, and expanded upon by Baron Montesquieu, a French political philosopher in the 1700s. (Online library of liberty, 2011) Montesquieu introduced the idea of a bipartite, and later a tripartite, system of government. The introduction of a tripartite system is unique to Montesquieu as political philosophers before him felt the judiciary was to be considered a separate institution rather than a distinct branch of government. (Locke, 1980, p.78) Montesquieu's tripartite system, consisting of three branches of government known as the executive, the legislative, and the judiciary, is most common in modern governments. Within this system, power is separated amongst the three branches and demonstrated by the distinct roles and responsibilities of each branch. The separation of powers amongst the different branches of government is essential to Montesquieu's belief that "when the legislative and executive powers are united in the same person, or in the same body of magistrates, there can be no liberty... Again, there is no liberty, if the judiciary power be 
not separated from the legislative and executive"; Montesquieu's belief explains that if power were not distributed amongst the different branches of government, "there would be an end to everything". (Documents of freedom, 2017)

James Madison, an American political theorist and president, coined a second method of power sharing. Madison introduced the concept of division of powers, or federalism. Madison wrote a series of Federalist Papers, throughout the 1700s, in which he discusses the concept of federalism and how the United States would operate effectively as a federal system. In a federal system, "regional governments are not subordinate to the central government. The federal and provincial governments each derive their authority from the constitution". (Saul K., 1953, p. 56) In Federalist Number 10, from November 23, 1787, entitled "The Problem of Faction in a Republic", Madison makes the case for why federalism should be adopted. Madison explains that if you have a small population, you will have fewer individuals and fewer interests, and therefore the population will more easily "concert and execute their plans of oppression. [If you extend] the sphere, and you take in a greater variety of parties and interest; you make it less probable that a majority of the whole" will have common interests. (Saul K., 1953, p. 56) This demonstrates that "the same advantage which a republic has over a democracy, in controlling the effects of faction, is enjoyed by a large over a small republic, -is enjoyed by the Union over the States composing it". (Saul K., 1953, p. 56) In essence, factions are more easily controlled when they are smaller, meaning that a divided government allows for greater success when the government convenes as whole, rather than having one large government body attempting to deal with every issue. Dividing the power of the government will not only create smaller factions to govern, but it will also divide responsibility. In turn, this division into factions will ease the process of governing a large populace.

Now that the theoretical origins of the separation of powers and federalism have been introduced, the two methods of power sharing can be analyzed in greater detail. This component of the essay will discuss how these methods of power sharing operate, specifically within a Canadian context. The Canadian government demonstrates the effective application of separation of power, as presented by Locke and Montesquieu. This system of governance, where power is separated, is referred to as the Westminster system. In Canada, power is separated amongst three branches of government known as the 
executive, the legislative, and the judiciary. As a constitutional monarchy, each branch within the system has its own unique roles and responsibilities. The first branch, the executive, is the "decision-making branch made up of the monarch as the head of state and the Prime Minister as the head of government" along with his or her Cabinet. (Snyder L. and Martin D., 2015) In Canada, the monarch is represented by the Governor General, who is appointed by the monarch at the recommendation of the Prime Minister. Next, the legislative branch is the law-making branch of the country, known as the Parliament of Canada. This branch consists of "the monarch, the House of Commons, and the Senate" and is responsible for creating legislation within a bicameral, or two-house, system. Finally, the judiciary, or judicial branch, is responsible for interpreting and applying the laws of Canada. This branch consists of "judges and courts" that operate independently of the other branches of government; this branch of government operates at both the federal and the provincial level. It is the responsibility of the judicial branch to "interpret and [apply] the law" and give legal advice to the government when it is sought. (Snyder L. and Martin D., 2015)

Although each branch of the Canadian government has its own unique role and responsibilities, it is necessary to understand the system of government that operates in Canada. Canada is a unique example when discussing the separation of powers because, although there are three distinct branches of government, Canada is classified as a bipartite system, rather than a tripartite system, as formally introduced through the work of Montesquieu. This phenomenon exists as the Canadian federal government operates as a fused system; this is referred to as a fusion of powers. The executive and legislative branches are intermingled as members of the executive branch, the Prime Minister and his cabinet, also hold seats in the legislature. Although this causes the two branches to be fused together, it is necessary to understand that they remain distinct, constitutional branches by law. Each branch of government has its responsibilities separated in a way that ensures each branch of government will verify the actions and responsibilities of another. (The idea file, 2011)

Along with Montesquieu's bipartite system, Canada also demonstrates the concept of federalism, as coined by Madison. Formally, federalism can be defined "as a division of powers between central and regional governments such that neither is subordinate to the 
other". (Dyck R. and Cochrane C., 2014, p. 431) It is important to note that, by this definition, there exists a clear distinction regarding "the relationship between national and provincial governments from that between provincial and regional governments". (Dyck R. and Cochrane C., 2014, p. 431) The relationships between the levels of government are generally outlined in a national constitution. Although the federal and provincial, or state, governments are equal to one another, each level of government has its own distinct responsibilities. (Dyck R. and Cochrane C., 2014, p. 431)

At the most basic level, some examples of federal powers are as follows: "trade and commerce; taxation; national defense; banking; criminal law; and interprovincial transportation and communication”. (Dyck R. and Cochrane C., 2014, p. 434) Some examples of provincial powers include "direct taxation within the province, public lands, hospitals and health care, municipal institutions, education, property and civil rights, and the administration of justice”. (Dyck R. and Cochrane C., 2014, p. 434) Municipalities, unlike the provincial and federal levels of government, do not hold individual assigned powers, but rather are acknowledged by the provincial government to "[have] the authority to enter into agreements with the Crown in right of Canada with respect to matters within the municipalities' jurisdiction". (Municipal Act, 2001, S.O. 2001, c. 25, 2016) Some matters within a municipality's jurisdiction include the following: "governance structure of the municipality and its local boards, financial management of the municipality, protection of persons and property, animals, and business licensing". (Municipal Act, 2001, S.O. 2001, c. 25, 2016) Ultimately, the purpose of distributing power amongst different levels of government, as explained by Madison, is to make it easier to govern an entire union by separating responsibilities and having smaller factions ensure those responsibilities are executed. (Padover, 1953, p. 56)

Federalism, as expressed by Madison, is a strategy often used to deal with the matter of factions in society. Without federalism, it would be impossible for all voices, and opinions or needs of the public, to be heard by the federal government. (Padover, 1953, p. 56) With responsibilities divided, the needs of a specific faction, if unable to be dealt with by the respective municipality, can be brought up to a higher level of government through the local representatives. Not only is federalism efficient in dealing with the needs of factions, but also if responsibilities were not divided, the federal government would be a single entity 
that is all encompassing in regards to decision making. By dividing federal responsibilities distinctly amongst the levels of government, federalism acts as another method of controlling the abuse of power.

Now that the separation of power and federalism has been analyzed, the methods by which these concepts prevent the abuse of power can be discussed. When considering both the separation of power and federalism, the abuse of power is prevented by the creation, and application, of a system referred to as "checks and balances". In order to understand the presence of the checks and balances in the Canadian government, it is first necessary to define this term. Among the three branches of government, checks and balances serve as a regulatory mechanism, allowing each branch to check up on the other. The main purpose of checks and balances is to "promote relatively deliberate, balanced, and moderate policy outcomes by ensuring that different institutional perspectives are effectively brought to bear on public affairs". (Knopff R. and Morton F. L., 2012)

The checks and balances system is necessary in the Canadian federal government because of the separation of power among the branches of government. Each branch has power delegated to it and a specific role to fulfill and it is this separation that creates the need for a system to ensure power is not being abused. (Dunn C., 2010) The executive, the legislative, and the judicial branches of government, as previously discussed, each consist of their own actors and their own individual role within the federal government. Upon presenting the role of each branch, it becomes apparent that the branches do not exist independently, but rather act based upon the principle of responsible government by holding the other branches accountable for their actions. This is how each branch demonstrates legitimacy in their actions and the actions of the other branches. Each branch "checks" the actions of another and as a result balances the power among them in order to ensure that power is not being abused, rights are not being infringed upon, and that administrative policies are being followed at all times. (Inwood G. J., 2012, p. 123)

Federalism, on the other hand, could be considered an extension of the separation of power. As mentioned above regarding the separation of power, power is distributed amongst the three branches of government in order to ensure each branch will "check" the actions of another, ultimately preventing the abuse of power. Distributing power even further by dividing a government into different levels is simply a continuation of the 
sharing of power and sharing of responsibilities within the political system. Without the division of responsibilities across different levels of government, not only would factions be difficult to control, but also it would be nearly impossible for the federal government to understand the needs of each faction. A lack of division of federal power would lead to the federal government acting as the sole decision making entity within a federation. Having different levels of government allows each level to operate as a smaller, independent government with the ability to control its own faction and employ its own system of checks and balances. Ultimately, federalism is another method to prevent the abuse of power within a political system. (Inwood G. J., 2012, p. 123)

Methods of sharing power, including the separation of powers and federalism, provide legitimacy in a political system by preventing the abuse of power. The purpose of this analysis is not to compare the concepts of the separation of power to federalism, but rather to provide context and express how both operate within a liberal-democratic state. Federalism and the separation of powers often coexist within single states, much like Canada, in order to prevent the abuse of power. The prevention of the abuse of power occurs because the separation of political power amongst different branches allows for a system of checks and balances to operate. This system will ensure branches of government operate within their realm and do not abuse their power. Federalism allows for the division of power through different levels of government; the sharing of responsibilities across this division ensures that government responsibilities are divided and power is not too deeply invested in one level. The concepts of separation of powers and federalism, coined in the 1700s, have become systems used to ensure political power is not abused and in turn, render a government as legitimate.

\section{Bibliography}

COMELL UNIVERSITY LAW SCHOOL. "Legal Information Institute: Separation of Powers" [online], https://www.law.cornell.edu/wex/separation_of_powers, (January 19, 2017). 
DOCUMENTS OF FREEDOM. "Separation of Powers with Checks and Balances", [online], https:// www.docsoffreedom.org/readings/separation-of-powers-with-checks-and-balances, (January 17, 2017).

DUNN, Christopher. The Handbook of Canadian Public Administration. Toronto: Oxford University Press, 2010, 568 pages.

DYCK, Rand and Christopher COCHRANE. Canadian Politics: Critical Approaches, Toronto, Nelson Education, 2014, 728 pages.

GOVERNMENT OF ONTARIO. "Municipal Act, 2001, S.O. 2001, c. 25", [online], December 10, 2016, https://www.ontario.ca/laws/statute/01m25\#BK11, (January 17, 2017).

INWOOD, Gregory J. Understanding Canadian Public Administration: An Introduction to Theory and Practice, Toronto, Pearson Canada Inc., 2012, 432 pages.

KNOPFF, Rainer and Frederick Lee MORTON. "Checks and Balances", In Rainer KNOPFF and Frederick Lee MORTON (dir. by), Charter Politics, Toronto, Thomas Nelson Canada, 1992, p. 197 to 233.

LEVIN, Lawrence Meyer. The Political Doctrine of Montesquieu's Esprit des Lois: Its Classical Background, Connecticut, Greenwood Press, 1973, 372 pages.

LOCKE, John. Second Treatise of Government, Indianapolis, Hackett Publishing Company Inc., 1980, 148 pages.

MAGNET, Joseph. "Separation of Powers in Canada", [online], 2013, Constitutional Law of Canada http://www.constitutional-law.net/index.php?option=com_content\&view=article\&id=24\&Itemid=38, (January 25, 2017).

MINTZ, Eric, Osvaldo CROCI, and David CLOSE. Politics, Power and the Common Good: An Introduction to Political Science, Toronto, Pearson Prentice Hall, 2006, 480 pages.

ONLINE LIBRARY OF LIBEERTY. "Montesquieu and the Separation of Powers", [online], April 13, 2016, http://oll.libertyfund.org/pages/montesquieu-and-the-separation-of-powers, (January 25, 2017).

PADOVER, Saul K. The Complete Madison: His Basic Writings, New York, Harper \& Brothers Publishers, 1953, 361 pages.

SNYDER, Lorraine and Dustin MARTIN. "The Constitution and Canada's Branches of Government" University of Alberta: Centre for Constitutional Studies, [online], 2015, https://ualawccsprod.srv.ualberta.ca/ccs/ index.php/constitutional-issues/democratic-governance/818-the-constitution-and-canada-s-branches-ofgovernment, (January 15, 2017).

THE IDEA FILE. “The Executive Power in Canada”, [online], https://janetajzenstat.wordpress.com/2011/05/31/theexecutive-power-in-canada/, (January 23, 2017).

TUCKNESS, Alex. "Locke's Political Philosophy", Stanford Encyclopedia of Philosophy, [online], 2005, January 11, 2016, https://plato.stanford.edu/entries/locke-political/, (January 23, 2017). 